\title{
Litterfall Production and Decomposition in Three Types of Land Use in Bengkulu Protection Forest
}

DOI: $10.18196 /$ pt.v9i1.4019

\author{
Enggar Apriyanto*, Fajrin Hidayat, Putranto BA Nugroho, Imanta Tarigan \\ Department of Forestry, Faculty of Agriculture, Bengkulu University \\ Jl. WR Supratman Kandang Limun Bengkulu 38371, Indonesia \\ ${ }^{*}$ Corresponding author, email: enggavan@yahoo.com
}

\begin{abstract}
Most of the social forestry program plantations in Bengkulu are in the form of mixed planting of coffee or rubber trees. The type of land use affects the production and decomposition of litterfall, which play an important role in nutrient cycle. The aim of the research was to determine the production and decomposition rate of litterfall in coffee (Coffee robusta) monoculture, coffee and Gliricidia sepium (gliricidia) agroforestry, and rubber (Hevea brasiliensis) monoculture. The research was arranged in a systematic design with three treatments and fifteen replications. The variables measured included production, composition, and decomposition rate of litterfall. The collected data were analyzed using T-test. According to the results, the litter production in coffee monoculture, agroforestry of coffee and gliricidia, and rubber monoculture was 1051.5, 1001.5, and $662.5 \mathrm{Kg} \mathrm{ha}^{-1} 4$ months $^{-1}$ with the decomposition rate about 5.13, 4.25, and 5.28 $\mathrm{gr} \mathrm{m}^{-2} 4$ months $^{-1}$, consecutively. The litterfall composition in the three types of land use consisted of leaf, twig, fruit, and flower. Leaf was the highest component of litterfall in coffee monoculture, agroforestry of coffee and gliricidia, and rubber monoculture, reaching 830.2 (78.99\%), 646.7 (64.73\%), and 391.0 (59.01\%) kg ha-1, respectively. Nutrition analysis of leaf litterfall indicated that the highest content of C, N, P, and K was observed in agroforestry of coffee and gliricidia compared to other plantation types.
\end{abstract}

Keywords: Agroforestry, Coffee, Litterfall, Production, Rubber

\section{ABSTRAK}

Pola tanam pada hutan sosial di Bengkulu umumnya berupa tanaman campuran antara tanaman kopi dengan pohon atau karet. Tipe penggunaan lahan berpengaruh terhadap produksi dan dekomposisi seresah. Tujuan penelitan adalah untuk menganalisis produksi dan kecepatan dekomposisi seresah pada tegagakan kopi (Coffee robusta) monokultur, agroforestri kopi dan Glirisidea sepium dan karet (Hevea brasiliensis) monokultur. Rancangan penelitian adalah sistematik sampling, tiga perlakuan dan 15 ulangan. Parameter yang diukur adalah produksi, komposisi, dan kecepatan dekomposisi seresah. Data dianalisis dengan menggunakan analisis T-test. Hasil menunjukkan bahwa produksi seresah pada tegakan kopi monokultur, agroforestri kopi dan G sepium dan karet monokultur berturut-turut sebanyak 1051,5, 1001,1, and 662,5 $\mathrm{Kg} \mathrm{ha-1} 44 \mathrm{bln}^{-1}$ dengan tingkat dekomposisi seresah adalah 5,13, 4,25, and 5,28 g m² 4 bln-1. Komposisi seresah pada tiga tipe penggunaan lahan terdiri dari daun, ranting kecil, buah, dan bunga. Produksi daun terbanyak selama empat bulan terjadi pada tegakan kopi monoculkur, diikuti agroforesti. C. robusta dengan G sepium, dan tegakan karet monokultur, secara berurutan sebesar 830,2 (78,99\%), 646,7 (64.3\%), dan 391,0 (59,01) kg ha-1. Kandungan C, N, P, dan K sersah daun tertinggi terjadi pada pertanaman agroforestri kopi dan G. sepium dibandingkan terhadap pola tanam yang lain. untuk tanaman karet.

Kata Kunci: Agroforestry, Kopi, Seresah, Produksi, Karet

\section{INTRODUCTION}

Forest ecosystem plays an important role in supporting humans living on the earth. The function of forest is to maintain water cycle, biodiversity conservation, climate regulation, environment services, air quality regulation, and soil conservation. Community forestry is a type of forest management involving society to fulfill the forest function. Forests have a good ability to accumulate and recycle nutrients if they left undisturbed. At certain time, they are generally able to create a nutrient supply that meets the minimum requirements for moderate growth. The nutrient requirement of plant varies between species. Some plants could grow efficiently on soils with a low level of nutrients, while others are able to grow well only on soil with moderate to good nutrition levels. The soil condition could limit the spatial distribution of tress (Kimmins, 1997).

Plants or trees fulfill their nutrient requirement through direct absorption of nutrients from solution in the soil. Nutrient uptake by roots from soil is an important mechanism. Direct uptake can oc- 
cur only from soil minerals that are in close contact with roots. The root pattern will affect the nutrients uptake. Besides, the mass flow of nutrient to roots will depend on the amount of water in the soil and the rate at which it moves toward the roots. It is also influenced by plant transpiration. Plants that have a good root pattern are more efficient in exploring the nutrition in soil solution. On the other hand, plants that have coarser roots with branches are less efficient in absorbing nutrients from the soil solution. In agroforestry practices, many plants are growing at the same place and time, which will perform the pattern of vertical distribution of roots in the soil. This condition shows the utilization of soil nutrition effectively, thereby increasing the soil productivity (Nair 1989; Donahue et al., 1983)

The quality of nutrient uptake by plants varies greatly, and the nutrients are distributed to all part of plants. The uptake of nutrients depends on the availability of nutrients in the soil and the requirement depending on species and physiological life forms. Plant at the development stage will require more nutrients compared to the mature one. The availability of nutrients in the soil could decline due to the result from reduction in the litter decomposition rates (Nyland, 2016).

During their life stages, plants always experience nutrients replacement due to the nutrient loss. Nutrient uptake by root system is a way to replace the nutrients lost. The nutrient loss in plants might occur through leaching due to rainfall or ground water, defoliation by herbivore, losses related with reproduction process, and litterfall of vegetative parts of plant such as leaves, branches, tree bark, and root (Donahue et al., 1983). Nutrient loss through leaf litterfall tends to occur more regularly compared to other mechanisms. In nature, organic matter is an importance source of nutrient for plant. It is also very important indicator of energy flow. The annual quantity of aboveground litterfall obviously depends on the proportion of the biomass that dies each year. The longer the foliage life and retention, the less the amount of leaf litterfall in the forest or plantation. The quantity and quality of litterfall are so important to fulfill the overall function of ecosystem (Kimmins, 1997).

The quantity of aboveground litterfall varies depending on the plant species, climate, soil moisture and soil fertility, and latitude. On the other hand, stand density has a little effect on the litterfall quantity. In the tropical forest, aboveground litterfall is distributed throughout the year with minor peak occurring in the drier months (Donahue et al., 1983)

Decomposition of litterfall and nutrients is an important part in the agroforestry or nutrients cycle in the forest. The decomposition rate of litterfall will determine the availability of nutrients in soil to be absorbed by root system. Excessive accumulation of litterfall with slow decomposition rate will develop undesirable soil condition, such as poor root development and lower productivity of forest or agroforestry (Nair, 1998). The decomposition rate of litterfall depends on the activity of the soil micro and macro-organisms, plants species, chemical composition of litterfall, $\mathrm{pH}$ of litterfall and forest floor, the soil microclimate, and the fertility status of the soil (Kimmins, 1997).

Community forestry development in protected forests leads to various forms of stands, which is a parameter to the productivity of the forest. In general, agroforestry system is applied in developing community forest. The production and decomposition rate of litterfall depend on the composition of the stands. Based on that conditions, it is important to study the production and decomposition of litterfall in the three types of forest stand, which are monoculture of coffee plants, monoculture of rubber plants, and agroforestry of coffee and gliricidia in protection forest. 


\section{MATERIALS AND METHODS}

The study was conducted in the protection forest area in Bengkulu from September to December 2015. Equipment used in the study included analytical balance, oven. caliper, bamboo, transparent plastic, shading net, max-min thermometer, label paper, and soil $\mathrm{pH}$ meter. Meanwhile, three types of land use were used in the study, including monoculture of coffee plants, monoculture of rubber plants, and agroforestry of coffee and gliricidia.

The research was arranged in a systematic design with three treatments and fifteen replications. The three types of land use were used as treatments, consisting of coffee monoculture, rubber monoculture, and agroforestry of coffee and gliricidia. The first sampling unit was determined randomly then the other sampling units were placed in systematic way with spacing of about $6 \times 6 \mathrm{~m}$ between sampling units.

The variables observed included the production and decomposition rate of litterfall in the three types of the land use. A litterfall trap with the size of $1 \times 1 \mathrm{~m}$ was used as an experimental unit to measure the production of litterfall. Fifteen experiment units were systematically placed in each type of land use. Litterfall accumulated in litterfall trap were collected and measured for its weight then separated according to the vegetative part. The observation was conducted every other week for three months.
The highest proposition of all biomass produced by plants is leaf litterfall (Kimmins. 1997) so that it was only used in the research to evaluate the decomposition rate of litterfall. The decomposition rate was measured using the litter bag technique, in which the leaf litterfall trapped at the first time was put into the litter/mesh bag with meh size of $2 \times 2 \mathrm{~mm}$ and then returned to the ground. The dry weight of leaf litterfall before returned to the ground was measured to know the initial dry weight and, at the end of the study, the dry weight of litterfall were measured again. The dry weight difference was then calculated to find the decomposition rate. Analysis of C, N, P, and K nutrients was conducted in laboratory of soil science, and the collected data were manually analyzed using T-test at 5\%.

\section{RESULTS AND DISCUSSION}

Based on the data analysis, the production of litterfall in the three types of land use was not much different from the first to the end of observation. During the research, the production of litterfall in the three types of land use always increased. The production rate of litterfall during two weeks in the coffee monoculture, coffee and gliricidia, agroforestry, and rubber monoculture plantation was consecutively about $13.14,12.59$, and $8.28 \mathrm{~kg}$ $\mathrm{ha}^{-1}$, in which the litterfall production in rubber monoculture plantation was the lowest. The different quantity of litterfall production was caused by

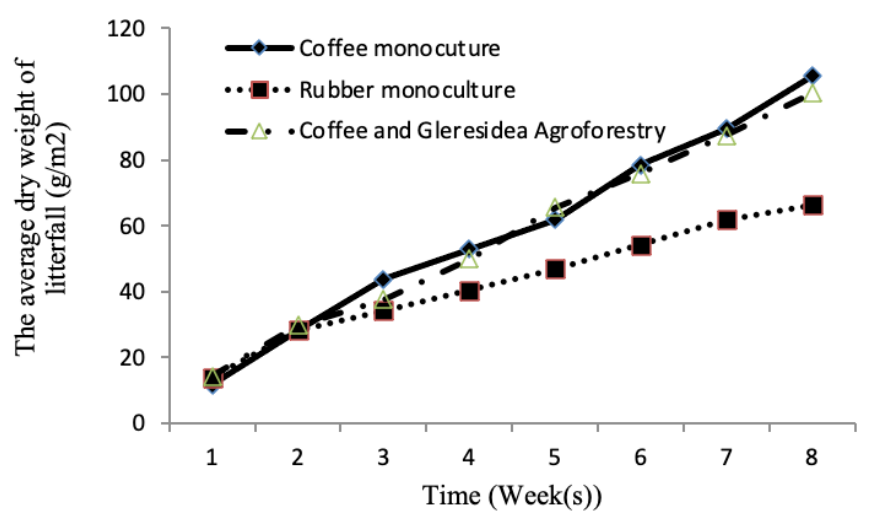

Figure 1. The production of litterfall in the three types of land use 


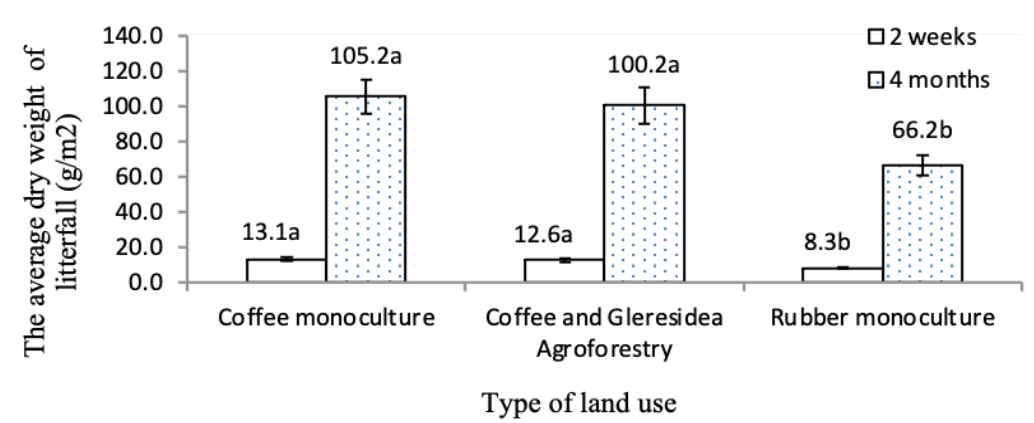

Figure 2. The production of litterfall in three types of land use two weeks and fourth months from initial observation

the different species composition in the land use. On the other hand, the production of litterfall in coffee monoculture plantation was similar to that in coffee and gliricidia agroforestry. This was due to that the main species composing both types of land use that was quite similar (coffee). The root system of coffee plants develops in the upper soil layer so that the growth of coffee plants is greatly affected by the weather, such as rainfall and humidity. During the study, the rainfall was low $(<300$ $\mathrm{mm}$ two weeks $\left.{ }^{-1}\right)$. This condition would decrease the soil water content in the forest area. To cope with dry conditions, the coffee plants lose their leaves to reduce transpiration. Consequently, the production rate of litterfall is higher compared to that of the plants with deep root system. DaMatta $\&$ Ramalho (2006) stated that earlier leaf senescence of coffee plant, especially in older leaves, would occur due to drought stress in dry season. Drought-sensitive clones of Robusta coffee lose considerable amounts of their leaves.

Kimmins (1997) states that one of the factors influencing the litterfall accumulation on forest floor is the composition of plant species. In this study, litterfall was always found in each observation in all types of land use so that the production increased constantly in four months. The production of litterfall in the three types of land use is presented in Figure 1.

The average of litterfall production in coffee monoculture, coffee and gliricidia agroforestry, and rubber monoculture plantation for four months was $105.2,100.2$, and $66.2 \mathrm{~kg} \mathrm{ha}^{-1}$, respectively (Figure 2). It showed that the lowest production of litterfall was in the rubber monoculture. The production of litterfall on the surface floor of plantation is affected by some factors, such as species, weather, and water availability. Plant root system is an important part of plant to absorb water and nutrients from the soil (Kolex \& Kozinka, 1992). Each plant develops different root system in appearance and extent of soil penetration. There is no doubt that the capacity of root system to absorb water and nutrients also differs greatly between each species. The root system of rubber tree is quit deeper compared to that of coffee tree so that in this study, the rubber trees had a good adaptability to the soil water availability and dry weather $(\leq 100$ $\mathrm{mm} / \mathrm{month}$ ) for 12 weeks since initial observation. According to Basuki and Tjasadihardja (1995), the rubber root system reaches up to $2.5 \mathrm{~m}$ in depth. With these characteristics of root system, rubber tree could be resistant to dry season so that the production of litterfall is lower than that of plants with the shallow root system. This condition supports the rubber tree to keep their leaves.

On the other hand, coffee plant has shallow root system so that they lose leaves as respond to the dry season and decreased availability of groundwater. Since coffee plant was the main plant composition in the coffee monoculture and agroforestry of coffee-gliricidia, the litter production in both types of land use was higher than in rubber monoculture. The plants adapt to dry season by losing leaves to 
Tabel 1. The composition of Litterfall on the surface floor of plantations during fourth months

\begin{tabular}{lcccccccccc}
\hline \multirow{2}{*}{ Land Use Types } & \multicolumn{1}{c}{ Composition of litterfall } \\
\cline { 2 - 12 } & \multicolumn{2}{c}{ Leaf } & \multicolumn{2}{c}{ Twig } & \multicolumn{2}{c}{ Flower } & \multicolumn{2}{c}{ Fruit } & \multicolumn{2}{c}{ Total } \\
\cline { 2 - 12 } & $\mathrm{g} / \mathrm{m}^{2}$ & $\mathrm{~kg} / \mathrm{ha}$ & $\mathrm{g} / \mathrm{m}^{2}$ & $\mathrm{~kg} / \mathrm{ha}$ & $\mathrm{g} / \mathrm{m}^{2}$ & $\mathrm{~kg} / \mathrm{ha}$ & $\mathrm{g} / \mathrm{m}^{2}$ & $\mathrm{~kg} / \mathrm{ha}$ & $\mathrm{g} / \mathrm{m}^{2}$ & $\mathrm{~kg} / \mathrm{ha}$ \\
\hline Agroforestry & 64.7 & 646.7 & 24.8 & 247.4 & 7.1 & 72.0 & 3.6 & 35.9 & 100.2 & 1001.5 \\
Gliricidia & 42.5 & 221.6 & 18.6 & 185.8 & 4.3 & 28.8 & 0.0 & 0.0 & 45.1 & 450.6 \\
Coffee & 22.2 & 425.1 & 6.2 & 61.6 & 2.9 & 43.2 & 3.6 & 35.9 & 55.1 & 551.3 \\
Coffee monoculture & 83.0 & 830.2 & 10.0 & 99.8 & 2.7 & 26.5 & 9.5 & 95.1 & 105.2 & 1051.6 \\
Rubber monoculture & 39.1 & 391.0 & 19.0 & 189.7 & 0.0 & 0.0 & 8.2 & 81.8 & 66.3 & 662.5 \\
\hline
\end{tabular}

reduce evapotranspiration (Riyanto \& Bintoro. consisting of $221.6 \mathrm{~kg} \mathrm{ha}^{-1} 4$ months $^{-1}$ (22.27\%) 2013). According to Kimmins (1997), the quantity gliricidia leaf litterfall and $425.1 \mathrm{~kg} \mathrm{ha}^{-1} 4 \mathrm{months}^{-1}$ of litterfall production is affected by weather, soil $(42.46 \%)$ coffee leaf litterfall. It showed that as water and nutrients, and plant composition. The shading trees, gliricidia contributed significantly density of plant affects the production of litterfall. to the litterfall production. Evizal at al. (2012) The higher the plant density, the higher the litter- also stated that shading trees of coffee plantation fall production (Syadri, 2002; Indarmawan, 2000; could contribute to the production of litterfall and Riyanto \& Bintoro. 2013). The existing litterfall is a good condition to return nutrients leaching out of the plantation (Abdoellah, 2013).

The production of litterfall in the agroforestry of coffee and gliricidia for four months was about $1001.5 \mathrm{~kg} \mathrm{ha}^{-1}$, consisting of $551.3 \mathrm{~kg} \mathrm{ha}^{-1}(55.05 \%)$ coffee litterfall and $450.6 \mathrm{~kg} \mathrm{ha}^{-1}(44.95 \%)$ gliricidia litterfall. The coffee litterfall was higher than that of gliricidia because coffee was the main plant in the plantation. Besides, gliricidia functioned as shading trees whose density was lower compared to that of the coffee plants. The production of plant biomass is distributed as leaf, twig, branch, root, flower, and fruit. Based on the measurement of existing litterfall (Table 1), the litterfall composition in the agroforestry of gliricidia and coffee consisted of leaves (64.73\%), twigs (24.70\%), flowerss $(7.19 \%)$, and fruit (3.38\%). It showed that leaf litterfall was the highest parts of litterfall produced in the land use. Kimmins (1997) states that leaf biomass is the highest part composing litterfall compared to other parts of plant. The production of leaf litterfall in the agroforestry of gliricidia and coffee was about $646.7 \mathrm{~kg} \mathrm{ha}^{-1} 4$ months ${ }^{-1}$ (64.73\%), nutrients returned to soil to be absorbed by plants. Coffee planted with shading tree at high altitude results in the high addition of organic matter in the soil (Notaro et al., 2014).

The production of litterfall in the coffee monoculture plantation during four months was about $1051.6 \mathrm{~kg} \mathrm{ha}^{-1}$, consisting of leaves, twigs, flowers, and fruits about 830.2 (78.95\%), 99.8 (9.49\%), $26.5(2.52 \%)$, and 95,1 (9.04\%) $\mathrm{kg} \mathrm{ha}^{-1}$, consecutively. It showed that the highest proportion of the litterfall was the leaf litterfall, reaching up to $78.95 \%$. It was followed by the litterfall of twigs (9.49\%), fruits $(9.04 \%)$, and flowers $(2.52 \%)$. Litterfall is an important material in returning nutrients into the soil through decomposition process, and it could protect soil from erosion.

The production of litterfall in the rubber monoculture plantation was about $662.5 \mathrm{~kg} \mathrm{ha}^{-1}$ for four months. There were no flowers found on the floor of the plantation since the flowering period had passed. The litterfall produced consisted of 391.0 $\mathrm{kg} \mathrm{ha}^{-1}$ (59.01\%) leaves, $189.7 \mathrm{~kg} \mathrm{ha}^{-1}$ (28.63\%) twigs, and $81.8 \mathrm{~kg} \mathrm{ha}^{-1}(12.36 \%)$ fruits. It showed that the leaf litterfall was the highest portion of 


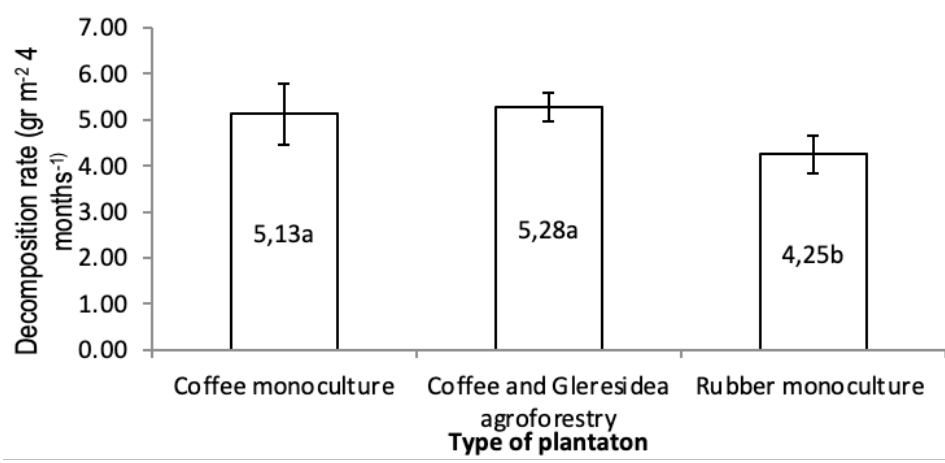

Figure 3. Decomposition rate of litterfall (gram ha-1 4 months $^{-1}$ ) on the surface floor of three types of land use in fourth months

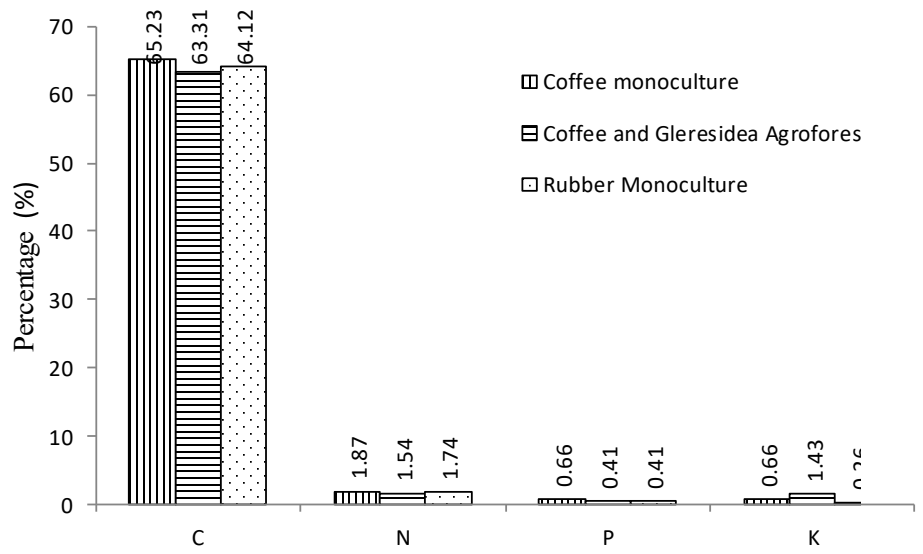

Figure 4. C, N, P, and K content of the Iktterfall in three different types of land use

the litterfall production, reaching up to $59.02 \%$ of coffee and gliricidia showed the highest rate, compared to other parts. Twigs and fruits were but it was not significantly different from that in about 28.63 and $12.35 \%$ of the total production of litterfall. According to Kimmins (1997), biomass of litterfall is distributed to leaf, twig, and flower and fruit, in which leaf is the highest biomass compared to other parts of plant. Because the study was conducted during dry season, the coffee plants adapted to the dry condition by losing their leaves to maintain the plant growth.

The decomposition rate of litterfall in the three types of land use was low because the study was conducted during dry season (Figure 3). The decomposition rate of leaf litterfall in coffee monoculture, agroforestry of coffee and gliricidia, and rubber monoculture was about 5.13, 4.25, and $5.28 \mathrm{~g} \mathrm{~m}-2$ 4 months $^{-1}$, consecutively. The decomposition rate in three types of land use showed significant differcoffee monoculture. The lowest rate of litterfall decomposition was in the rubber monoculture plantation due to low humidity of rubber plantation. The production and decomposition of litterfall will affect organic matter on the soil surface of plantation as source of nutrients absorbed by plants. The organic matters are decomposed before being absorbed by plant root system. Decomposition is the process of organic matter breakdown into basic constituents of carbon dioxide, water, inorganic nutrients, and energy. Decomposition of leaves begins when leaves are still on the plant approaching senescence, and the plant reabsorbs nutrients from senescence leaves into permanent part of plant (Kimmins, 1997).

The nutrition analysis of leaf litterfall indicated ence. The decomposition rate in the agroforestry that the content of $\mathrm{C}, \mathrm{N}, \mathrm{P}$, and $\mathrm{K}$ in the agrofor- 
estry of coffee and gliricidia was 65.23, 1.87, 0.66, and $0.66 \%$, respectively. Meanwhile, in the coffee and rubber monoculture, the content of $\mathrm{C}, \mathrm{N}, \mathrm{P}$, and $\mathrm{K}$ was $63.31,1.54,0.41$, and $1.43 \%$ and 64.12 , $1.74,0.41$, and $0.26 \%$, consecutively (Figure 4). The content of $\mathrm{C}, \mathrm{N}, \mathrm{P}$, and $\mathrm{K}$ nutrients in the three types of land use was not much different. The nutrients content of gliricidia leaf was higher because this plant associated with bacteria that could help plant pick-up nitrogen from atmosphere. The nutrients of litterfall play an important role to maintain the soil quality in the plantation. The species of shading trees also significantly contribute to the addition of nutrients in soil. Coffee planted with several shading trees had quite similar production to that planted without shading trees (Prawoto, 2008).

\section{CONCLUSION}

The production of litterfall in the agroforestry of coffee and gliricidia (1001.2 kg ha $\left.{ }^{-1}\right)$ was lower than that in coffee monoculture (1051.6 $\left.\mathrm{kg} \mathrm{ha}^{-1}\right)$, but higher than that in rubber monoculture $(662.5$ $\left.\mathrm{kg} \mathrm{ha}^{-1}\right)$. However, the fastest decomposition rate and the highest nutrition contents were observed oin the agroforestry of coffee and gliricidia. This study needs to be conducted for longer period, covering dry and rainy season.

The highest litterfall production was observed in the coffee monoculture (1051.6 kg ha' $\left.{ }^{-1}\right)$, followed by the litterfall production in agroforestry of coffee and gliricidia (1001.2 $\left.\mathrm{kg} \mathrm{ha}^{-1}\right)$, and the litterfall production in rubber monoculture was the lowest $\left(662.5 \mathrm{~kg} \mathrm{ha}^{-1}\right)$. Meanwhile, the fastest decomposition rate and the highest nutrition contents were observed in the agroforestry of coffee and gliricidia. To perform comprehensive study on the litterfall production, this study should be conducted in a longer period covering dry and rainy season.

\section{REFERENCES}

Abdoellah. S. 2013. Integrated Plant Nutrient Management on Coffee Plantation. Review Penelitian Kopi dan Kakao 1 (1) 2013. 23-39.

Basuki \& Tjasadihardja. A. 1995. Rubber Research Information. Vol.14 No.2 (89-101) Juni 1995. Plantation Research and Development Association. Published by Monor. Medan. 91-92p.

Evizal, R., Tohari, Prijambada, I. D. \& Widada, J. 2012. The status of litterfall on the contribution of $\mathrm{N}$ and $\mathrm{P}$ in the coffee agroecosystem. GROTOP, 2(2):177-183

Donahue, R. L., R.W. Miller, \& J.C. Shickluna. 1983. Soils. An Introduction to Soils and Plant.

DaMatta, F.M \& Ramalho, C.D. 2006 Impact of drought and temperature stress on coffee physiology and production: A review. Braz. J. Plant Physiol., 18(1):55-81

Indarmawan. 2000. Production and litter decomposition rate Sengon And Turi ON Land Former Coal Mine. Thesis Department of Forestry. University of Bengkulu. (unpublished).

Kimmins, J. P. 1997. Forest Ecology: Fundamental for Sustainable Management. Prentice Hall, Inc. Simon \& Scuster/ A.Viacom Company. Upper Saddle River. New Jersey.

Kolex, J. \& V. Kozinka. 1992. Physiology of the plants root system. Kluwer Academic Publishers. London.

Nair R. P. K. 1989. Agroforestry Systems in the tropics. Kluwer Academic Publishers. in collaboration with ICRAF. 664 pages. ISBN 90-247-3709-7.

Notaro de Alcantara, K., Valenta de Medeiros, E., Duda, G. P., Silvia, A. 0., \& Maia de Moura, P. 2014. Sci. Agric. v.71, n.2, p.87-95,

Prawoto, A. A. 2008. Coffee yield and Mineral cycle in intercropping of coffee and some species of timber shade trees. Pelita Perkebunan, 24(1) 1-21.

Riyanto, I, A. \& Bintoro. 2013. Produksi Seresah Pada Tegakan Hutan Di Blok Penelitian Dan Pendidikan Taman Hutan Raya Wan Abdul Rachman Provinsi Lampung. UNILA. Lampung.

Syadri. H. 2002. Production and The rate of decomposition of leaf litter Wood Onions (Protium javanicum Burm F.) in the village of Lubuk Here Taba Penanjung North Bengkulu. Thesis Department of Forestry. University of Bengkulu. NOT be published 